This item was submitted to Loughborough's Research Repository by the author.

Items in Figshare are protected by copyright, with all rights reserved, unless otherwise indicated.

\title{
'There are times when I feel like a bit of an alien': Middling migrants and the national order of things
}

\section{PLEASE CITE THE PUBLISHED VERSION}

https://doi.org/10.1111/nana.12422

\section{PUBLISHER}

(c) The author(s) 2018. Nations and Nationalism @ ASEN/John Wiley \& Sons Ltd 2018

\section{VERSION}

AM (Accepted Manuscript)

\section{PUBLISHER STATEMENT}

This is the peer reviewed version of the following article: SKEY, M., 2018. 'There are times when I feel like a bit of an alien': Middling migrants and the national order of things. Nations and Nationalism, 24(3), pp. 606623, which has been published in final form at https://doi.org/10.1111/nana.12422. This article may be used for non-commercial purposes in accordance with Wiley Terms and Conditions for Use of Self-Archived Versions.

\section{LICENCE}

CC BY-NC-ND 4.0

\section{REPOSITORY RECORD}

Skey, Michael. 2018. "'there Are Times When I Feel Like a Bit of an Alien': Middling Migrants and the National Order of Things". figshare. https://hdl.handle.net/2134/32045. 


\section{'There are times when I feel like a bit of an alien': Middling migrants and the national order of things}

\section{Abstract}

This paper considers the value of using the experiences of what have been labelled as 'middling migrants' to explore the ways in which people continue to understand the world and their own place in it in national terms. It begins with a critical engagement with the literature on banal, hot and everyday nationalism, arguing for a more dynamic model that not only tracks the processes by which largely taken-for-granted forms and practices are opened up to scrutiny and vice versa but also their significance, as both mindful and mindless features of daily life. The second part explores how these processes may operate by focusing on a particular group of migrants; Britons in Australia. The experiences of these people are particularly useful in researching everyday nationalism's evidence problem because they occupy an in-between space, not quite 'us' nor 'them', that can be used to reflect on the shifting salience, and significance, of the nation in daily lives. As well as noting how differences relating to language, food and interactions come to be framed as 'national', the study also shows the extent to which novel circumstances become part of the taken-forgranted lifeworld over time.

\section{Introduction}

Two decades on from the publication of Michael Billig’s landmark thesis of Banal Nationalism, we now have a body of research that demonstrates the extent to which banal markers continue to flag the nation on a daily basis. However, as Craig Calhoun (2017) has argued, there is a problem with simply observing that 'there is banal nationalism'. For 
Calhoun the crucial point to make is that banal forms of nationalism are 'crucial to the rest of nationalism'. This relationship has been somewhat under-theorised in the literature and in the theoretical part of this paper I argue that we need to try and move beyond the binaries of hot/banal and everyday/banal to focus on two analytic levels.

The first is much more obvious, and well researched, and deals with the range of practices and dispositions, whether mindful or mindless, that reference or represent a given nation. A useful starting point, here, is Jones \& Merriman’s (2009) study of ‘hot, banal and everyday nationalism' as it foregrounds the varying meaningfulness of particular signs or practices as well as the ways in which the everyday realm can become a site of struggle between different groups. I look to build on these insights by arguing for a dynamic model that tracks the processes by which largely taken-for-granted forms and practices are opened up to scrutiny, and vice versa, but also their significance, as, alternatively, largely overlooked or contested features of daily life. In this way, we can move beyond simply labelling these forms or practices, to more effectively theorising their value, whether as individual markers or as part of a wider, established social structure.

The second analytic level deals with the cumulative impact of such features and the extent to which they recreate and stabilise the idea that we live in a world of nations. This is an important aspect of Billig's work that often gets overlooked in the rush to identify this or that quotidian feature. Indeed, we sometimes risk missing the wood for the trees when evaluating the significance of nationalism in the contemporary era. Put simply, our interest should not just be about identifying national talk, flags or barcodes but theorising the contribution that each of these features as a whole makes to the wider institutionalised structures that, in turn, underpin inter/national frameworks and make them hold good.

The second part of the paper will shift to focus on the tricky question of how best to study 
such processes. Here, it is argued that the experiences and views of middling migrants may be one way of addressing the ‘evidence problem’ identified by the editors of this collection. These are people confronted with a relatively novel set of circumstances but who can often mitigate against the most challenging aspects of living in a new place by drawing on greater levels of economic and cultural capital. In a position to reflect on the relative unfamiliarity of 'new' ways of being and behaving and, in some cases, how these become 'naturalised' over time, such groups may be able to provide us with fresh insights into the salience, and significance, of the national in people’s daily lives. The third part uses a number of illustrative examples to explore how a range of everyday features (relating to language, food and social interactions) come to be discussed and evaluated as distinctly 'national' and thus seeks, once again, to privilege a more dynamic view of the relationship between the different categories of nationalism identified in the literature.

\section{Banal, everyday and hot nationalism}

An early critique of Billig's thesis was that it tended to operate in terms of two fairly monolithic categories, banal and hot nationalism. Instead, it was argued that any focus should be on processes of heating and cooling and also that the emergence of banal forms of nationalism should be viewed as an achievement that benefited some at the expense of others (Condor, 2000). Another productive way of thinking about the relationship between hot and banal forms of nationalism has been offered by Jones \& Merriman (2009). Initially, taking issue with the 'unwarranted separation of the banal and hot processes that reproduce nationalism' they argue for the 'promotion of the idea of everyday nationalism, which combines banal and hot elements in more complex and contingent ways (Merriman \& Jones, 2009: 164). In other words, in addition to being a site of banal and mundane processes, the everyday “may also incorporate a variety of hotter 'differences and conflicts' that affect 
people’s lives on a habitual basis” (Jones \& Merriman, 2009: 166). Such an approach is centred on the idea that the everyday realm is where most activities take place and where people generally experience and make sense of the world and those they encounter As well as being used to flag this temporal dimension, the term 'everyday nationalism' has also been used to indicate the ways in which ordinary people are actively involved in reproducing national ways of being and doing (Thompson, 2001, Fox \& Miller-Idriss, 2008). Such approaches, emphasising human agency and reflexivity, are usually contrasted with Billig's rather top-down, one-dimensional and depopulated notion of banal nationalism (Knott, 2016).

While placing people at the heart of any analyses is, of course, important, this way of distinguishing everyday and banal nationalism also risks trading in rather crude categorisations at times. In this case, we have those who actively produce or, indeed, challenge national frameworks to meet their needs contrasted favourably with the 'nationalist dupes’ (Fox, 2017: 30) whose engagements are largely unthinking. It also downplays the changing ways in which individuals and groups may shift between more or less reflexive pronouncements or practices.

Indeed, these shifts are what I want to emphasis, here, as while the binaries hot/banal and everyday/banal often a useful starting point for thinking about different types of national practice they suffer from two significant drawbacks. First, they aren’t always able to capture the ways in which different groups are positioned in relation to a given activity or feature or how these relations may change over time. As much empirical work has shown, the same everyday feature (a street sign, say, or a product being sold in a shop) may generate an outpouring of nationalist fervour in some, whilst being largely ignored as part of the 'normal' background scheme of things by others (Jones \& Merriman, 2009: 169). Likewise, as we will 
see later, at particular moments a given practice, product or symbol may shift from being part of the unquestioned backdrop to everyday lives to being something that is actively debated or reflected upon. Second, more attention needs to be focused on theorising the significance of these different types of national practice. What might be the value of an activity or feature that most people within a given country barely give a second thought to? And to what extent is its meaning different from those that involve more active engagement or become subject to contestation or critique?

The next section focuses on this key issue, again arguing that thinking about these issues in relation to different analytic levels helps focus attention on both the importance (or otherwise) of individual practices as well as their overall significance in consolidating a coherent framework for thinking about and acting in a world defined in national terms.

\section{National practices}

To reiterate, labelling forms of nationalism as hot, banal or everyday shouldn't be seen as an end in itself but as part of a project to understand the relationship between these different forms and, just as importantly, to help us theorise the significance of nationalism in the contemporary era.

If we begin by attending to more reflexive or instrumental activities, then much of the work exploring hotter forms of nationalism has emphasised the ways in which groups mobilise so as to more effectively secure access to key economic and symbolic resources. However, we should also acknowledge their potential value in terms of the subjectivities they produce as well, notably when it comes to those whose sense of belonging to the nation remains largely beyond question. For instance, actively participating in broadly shared, well established and often venerated cultural practices (patterns of eating and drinking, humour, sports and 
pastimes, ceremonial occasions, discussions of media content) not only confers social status for those recognised as belonging but can be both comforting and enjoyable. This is what Pete Bratsis labels as, 'the libidinal value’ of group belonging (2000: 92) and while we should certainly be aware that these activities can involve forms of stigmatisation or exclusion, it is also worth noting what they offer particular groups and, in turn, why they may become so vigorously defended in the face of scrutiny or challenge.

But what of national practices that are largely habitual or unthinking? Often those involved have been caricatured as naïve or unsophisticated in contrast to those who critically reflect on their lives. Yet as Mark Haugaard argues, 'being reflexive, questioning the essence of what people do and say takes effort. It would not be possible to get out of bed in the morning, never mind speak a language, if all meaning were’ opened up to constant scrutiny (2002: 130). Put simply, the un-waved flags and barely acknowledged forms of talk and practice matter because they can be relied upon and, hence, ignored. In other words, they smooth social interactions, allow people to get on with their lives and, in the process, generate a sense of comfort and familiarity (Skey, 2011). This is why when such features or practices are removed or altered they generate so much consternation (Skey, 2010, Wise, 2010), somewhat akin to the breaches that Garfinkel's students caused when looking to interrupt everyday social norms in the home.

Having briefly outlined an approach for thinking about the possible significance of individual practices, I now want to argue that moving beyond the level of individual and group activity centred on a particular goal or opponent enables us to shine a spotlight on another aspect of the relationship between banal and other forms of nationalism.

\section{The value of national frameworks}


When thinking, in more general terms, about the value of established socio-political frameworks, we can first point to the wealth of research on the extent to which largely takenfor-granted habits, routines and rhythms are crucial in allowing individuals to co-ordinate their activities and get things done in a relatively unproblematic manner (Berger \& Luckmann, 1967, Kertzer, 1988, Jenkins, 2002). These features also introduce an element of certainty and stability into what otherwise might be seen as a complex, overwhelming and sometimes frightening world. As the anthropologist David Kertzer observes;

The world out there confronts each individual with an infinite number of stimuli, yet no one can deal with all of them. [A degree] of order is ... provided by the symbol system we learn as members of our culture ... Such ... systems provide us with a shield against terror' (1988: 4)

Now, there is still a good deal of evidence that for a substantial number of people around the world, national frameworks are one such 'system’ that is sustained through relatively consistent and patterned spatial-temporal regularities, institutional arrangements and shared practices (Skey, 2011). In this way, they contribute to the maintenance of a 'frame of reference that, in spite of its inconsistencies ... is nonetheless sufficiently integrated to be used for solving [many] .. of the practical problems at hand' (Schutz \& Broderson,1976: 233). Of course, the development and maintenance of such a framework is not benign, it involves relations of power and acts of domination and oppression. For those, however, that form part of the ‘dominant majority’ (Kaufmann, 2004) within a given national setting, this framework often provides a key sense of self, place and community.

Having argued for the importance of drawing an analytical distinction between individual national practices and wider national frameworks, in the next section, I want to shift focus by briefly acknowledging a methodological challenge. For while, finding evidence for more 
overt expressions of national practice is relatively straightforward, 'uncovering the covert workings of nationhood in everyday life' (Fox \& Van Ginderachter, this issue) represents much more of a tricky issue. In order to address this challenge, I suggest that a particular group of migrants may provide a fruitful avenue for not only teasing out the shifts from taken-for-granted to more explicit expressions of nationalism but also understanding their relative value in grounding people’s connections to place and each other.

\section{Uncovering evidence}

Recent research on nationalism has seen a move away from more top-down investigations into the role of powerful institutions in inculcating banal nationalism (the media, political institutions, the education system) to address the everyday performance of the nation by ordinary people. Much of this work has been interesting and some attempts have been made to pinpoint the ways in which national frameworks operate as 'an unreflexive habit [or] ... and unselfconscious disposition' (Fox \& Ginderachter, this issue) by drawing on the tenets of conversation analysis and studying features such as 'reciprocity of perspective' when discussants, for example, do not feel the need to explain particular points or laugh in unison at a joke based on insider 'national' knowledge (Hester \& Housley, 2002).

Elsewhere, other scholars in psychology are using experimental investigations to study the 'implicit activation of national cues’ (Butz, 2009, Hassan et al, 2009), how nationalism is used to justify political projects and systems (Carter et al, 2011, van der Toorn et al, 2014) and hierarchies of national belonging (Devos \& Banji, 2005). Such experiments represent one attempt at breaching people’s everyday understandings so that they come to articulate national preferences and orientations. A related form of breach can be identified when studying the conversations of 'ordinary' people as they discuss perceived challenges to a previously settled state of affairs. For instance, a study of members of the ethnic majority in 
England (Skey, 2010) showed how such individuals often become noticeably agitated when discussing the presence of 'foreign' goods or voices on the high street, the apparent privileging of non-nationals over nationals, the celebration of 'foreign' sports teams and so on.

This paper deals with another possible means of generating such 'evidence' by focusing not on a novel method but another group who have been relative under-theorised in the literature, relatively affluent (or middling) migrants moving between, and settling in, places that are not altogether dissimilar. The experiences of these people are particularly useful in researching everyday nationalism's evidence problem because they occupy an in-between space, “neither completely foreign nor entirely familiar” (Pearson, 2014: 504), that can be used to reflect on the shifting salience, and significance, of the nation in daily lives. In studying these processes, and the changing position of particular groups - migrants and members of the host population - in relation to such practices, we are offered key opportunities to identify the extent to which people continue to make sense of everyday objects and interactions in national terms, thereby unveiling the continuing significance of a national framework in patterning their lives.

The literature on migration has, of course, mushroomed in recent times as both physical and virtual mobility has dramatically increased for populations around the globe but much of this work has focused on either the most vulnerable or elite groups. The following sections, first offer a brief overview of some of this literature, before providing a rationale for the approach to be used in this paper.

\section{Middling migrants}


In 2015, the UN estimated that there were over 244 million international migrants around the globe (United Nations, Department of Economic and Social Affairs, Population Division, 2015). Combined with these movements in people is the associated growth in flows of products, images and ideas across international borders (Giddens, 2002). Much of the work around these topics has been stimulating tracking the emergence of both new forms of sociability and the organisations that underpin them. However, a large proportion of the research in this area has either focused on the movement of groups from poorer to more affluent parts of the globe or the activities of highly-skilled, footloose migrants who are seen to form a cosmopolitan global elite. Alternatively, as Conradson \& Latham write;

There exist a host of other types of mobility that similarly involve ... the maintenance of enduring ties across international borders, but which have so far escaped the transnational literature ... What is striking about many of the people involved in these kinds of transnational travels is their middling status position in their countries of origin. They are often, but not always, well educated. They may come from wealthy families, but more often than not they appear to be simply middle class. In terms of the societies they come from and those they are travelling to, they are very much of the middle. But the fact is that surprisingly little is known about these kinds of migrants’ (2005: 229)

Of the work carried out in this area, Michael Peter Smith’s $(2001,2005)$ has been perhaps the most influential, emphasising the role of middle-class migrants in developing and sustaining trans-national networks and institutions in key urban centres. In doing so, Smith has persuasively argued for the importance of attending to the 'socially situated subjectivity of human agents while also providing a way to study spatially distanciated social relations’ (Smith, 2005: 235). While Smith has argued that studies of middling migration must also 
attend to local structures, including those associated with the nation-state, scholars of nationalism have paid relatively little attention to the phenomenon. A notable exception is David Pearson (2001, 2014), who is also one of the few people to have carried out research on UK migrants living in Australia and New Zealand (See also Bell, 2009, McGlynn et al, 2011, Fraser \& McCarthy, 2012). Pearson not only notes the shifting regional and national allegiances that such migrants articulate in response to different contexts and prompts but also how a position of relative power, as someone from a white, Western background, can be undermined by a lack of “vernacular cultural credentials” (Pearson, 2014: 517, see also Bell, 2009) at particular moments. This is a point that will be picked up in the analyses of my own empirical materials but in the next section, I want to outline how these materials were generated and analysed.

\section{Brits in Australia}

In looking to research the views and activities of people moving between Britain and Australia for extended periods of time, my reasoning had been that these people would experience less overt discrimination, be able to draw on a wider range of economic and sociocultural resources and would feel relatively 'at home' in their new environment given the long history of cultural, social and economic exchange between the two countries. British Empire settler states, like Australia, were not only formed and managed by English migrants but also renewed by subsequent waves of migration from England (and the rest of Britain). This meant that "until well into the twentieth century, the majority of ... [Australians] with such origins were quite at ease seeing themselves as 'British' as well as local born (Pearson, 2014: 505). With the growing diversity of the Australian population, not to mention some attempts to reposition the country as part of Asia, these historic ties have been called into 
question. Notwithstanding this, it is probably fair to say that a 'shared' imperial past continues to shape relations between the two countries, albeit now often discussed in relation to the Commonwealth, the English speaking world and the Anglosphere. At the same time, Australia and Britain are not interchangeable, notably when it comes to accent, colloquial language, key institutional frameworks (education, healthcare, pensions and so on) and forms of socio-cultural knowledge (notably who and what counts as important).

The main data collection period was May-June 2013, which is when I travelled to Australia and conducted 14 interviews in and around Sydney and Brisbane with respondents that had been contacted through a process of snowball sampling. Seven of the interviews were with individuals, five involved two people (including two couples) and I conducted two larger group interviews, with four people in each. In total, I spoke to 25 people. My aim was not to generate a representative sample of British migrants in the two cities, but to try and focus on professionals rather than, say, those working in the hospitality industry. Here, the assumption was that the former would be more able to mitigate any potential challenges by drawing on a wider range of socio-economic resources. All those I interviewed were also white, so would not be visibly different from the dominant, majority Australian population.

I made an effort to speak to more recent migrants as well as those who had been living abroad for some period of time. The questions that I asked were kept deliberately open to encourage respondents to talk about the issues that were important to them. For example, I opened the interview by asking them to tell me how they had come to be living in Australia before moving on to their experience of travelling, what they dis/liked about their new place of residence and whether (and how) they maintained connections with 'home'. In analysing the data, I drew on insights from Membership Categorisation Analysis (MCA, Baker, 1997) and 
focused, in particular, on the manner in which deictic forms of language (we, us, here, there) were used to categorise people, places and products in national terms and/or how discussions were informed by a shared understanding of a world that is defined by national differences, priorities and norms.

In the remaining space, I will briefly outline some of the more general features of the interview data before focusing on some illustrative examples, relating to food, language and social interaction, which are of particular relevance to my overall argument.

The comfort of (relative) strangers

Most of the people interviewed found it relatively easy to adjust to their new life abroad emphasising similarities in language, culture and history. For those who had struggled being away from 'home' or knew of others who had returned, missing family and friends was the primary issue. Not surprisingly the distance between Australia and Britain was the major obstacle and many had sought to overcome this (at least, partially) through the uses of a range of communication technologies, including Facebook, Vyber, Skype, WhatsApp and email.

In terms of 'their' relations with the host population, none of the people I spoke to had experienced any outright discrimination beyond the odd bit of 'banter', often based around sport. Any sense of 'difference' was primarily tied to their accent and/or use of language but this generally provoked curiosity rather than antipathy (more of which below). Interestingly, many admitted that the shared experience of moving, alongside a lack of shared reference points with those from the host population, often meant that migrants made friends with conationals although for some this situation abated over time. 
As a result, most felt comfortable in their new environments and spoke passionately about the opportunities that migration had given them. Many struggled with the idea of returning 'home'. Often being in-between places was identified as the perfect solution, able to take advantage of the best of both 'worlds'. Yet in amongst these 'cosmopolitan' orientations, the nation continued to form a taken-for-granted backdrop to many of the discussions. In some cases, this was obviously a direct result of the questions I asked. But also noticeable was the extent to which people's understanding of their experiences was defined in national terms whether in adjusting to new situations or describing their relations with others. Second, while new connections with local people and places were generally valued, none of my respondents claimed a new national identity for themselves, including the people who had taken on dual citizenship. In other words, people travelled between nations, identified themselves and others in national terms (including the use of a whole host of deictic markers, us, we, them, here, there) and made sense of their lives through the prism of the national. In the final sections of the paper, I want to focus on a number of illustrative examples that not only demonstrate the ongoing relevance of this prism but also highlight the importance of the processual model discussed earlier.

\section{Linguistic breaches (and the comedy value of the national)}

In this section, I want to focus on the role of language in not only demonstrating the varying meaningfulness of particular practices for middling migrants and members of the host population but also how everyday interactions between these two groups can help us unveil a taken-for-granted framework for making sense of the world. In relation to my own data it's worth noting that while most Australians and British people share the same 'mother' tongue, 
each country features a range of colloquial words and phrases that are not generally used in the other. Therefore, language can be seen as a key marker in establishing an individual's “vernacular cultural credentials” (Pearson, 2014: 517) and linguistic anomalies were a notable topic for discussion among many of my respondents. Examples of these included both the use of unfamiliar words, lollies (instead of sweets), bottle shops (instead of 'off licences' - where alcohol can be purchased), pants (instead of trousers) as well as the (over) use of phrases such as 'No worries' and the constant shortening of words combined with the adding of an ' $\mathrm{O}$ ' at the end.

Ian: We've got to go to the Servo [service station] ...

Claire: Bottle o [off licence], smoke o [cigarette break]

(laughing)

Claire: Everything ‘o’ (English, aged 40’s, living in Queensland, Australia)

Likewise, novel accents were a source of interest and/or mirth as the following example demonstrates;

Steve: They wouldn't be nasty but they would say, oh say that again, that's really funny.

Jenny: Can you say that again, it’s really funny.

Steve: Oh I get it at work. 
Jenny: Yeah.

Steve: $\quad$ All the time (English, aged 30’s, living in Sydney)

These extracts show the manner in which variations language use can generate puzzlement, causing individuals to reflect on the peculiarities of a particular situation and hence their own status and place within it. The middling migrants are forced to confront a new dominant way of speaking, while these interactions cause certain words and phrases to shift from being part of what most people know as a matter of course to being actively discussed, at least temporarily. The fact that such 'shifts' generate amusement rather than antipathy is noteworthy as it stands in contrast to much of the extant literature on migration and language use, which has demonstrated the extent to which those who are perceived as having particular ‘foreign' accents are subject to both direct and indirect forms of discrimination (Lipper-Green, 1997).

\section{Getting the joke}

Asides from noting the relatively privileged status of these migrants, two further points are worth making at this juncture. First, the benign nature of these interactions doesn't mean that they are unimportant. In almost all these cases, incidents occurring in very local contexts (with work colleagues, at the shops) were framed in terms of wider national differences. In Steve's case, the 'they' in question may not be referencing Australians in general but is certainly referring to Australian work mates, who would be, after all, the only ones likely to consider Steve’s accent to be unusual and hence worthy of further attention.

The humorous nature of the exchange is also worth acknowledging. The ways in which comedy has been used to inform particular forms of national identity has been explored in 
some detail (Medhurst, 2005) but there has been less interest in the way that both comedians and 'ordinary' people use national differences as the punchlines for jokes. Rather than dismissing such activities as inconsequential, we should actually be aware that audiences getting jokes that play on national differences are one of the best examples we have of the ways in which a largely taken-for-granted national framework operates.

For instance a recent study by Amanda Wise (2016) argued that joking relationships were often key in cementing forms of workplace conviviality among heterogeneous workforces in Australia. Interestingly, many of the examples Wise uses emphasis national differences and caricatures with Aussies, Filipinos, Indians, Pakistanis and 'Lebs' all becoming the butt of jokes. While at the surface level such exchanges can be usefully classified as forms of everyday nationalism that allow people to orientate themselves towards each other, we should also be aware that they point to the deeper (national) framework of understanding that allows such jokes to be meaningful in the first place.

\section{'Making fun of your nationality'}

We can also see an echo here in some of Adrian Favell's (2008) ground-breaking work on what he labelled as 'Eurostars'. These are well-educated, middle-class workers born in one European country but taking advantage of one of the tenets of the European Union, freedom of movement, to settle in another country, usually a major European city. For many of those he interviewed, national categories and differences did not become irrelevant but were used as a means of both orientating oneself towards co-workers and, above all, participating in ‘fun’ activities. As one respondent noted; 
I'm German but it's great fun being European and making fun of your nationality and other nationalities. That's a game with the identifies that you can observe a lot around here, which I like a lot (quoted in Favell, 2008: 9)

Finally, a recent project studying the Eurovision Song Contest (Kyriakidou et al, 2017) a televised music competition between European nations, noticed similar practices among fans at the event. Initially when meeting strangers, national categories and, in some cases, stereotypes were again used to 'break the ice' and generate rapport, often in a fairly convivial and humorous manner.

The second point to make in relation to these features is again the importance of adopting a dynamic approach. In the case of accents, many of those I interviewed who migrated with families said that their children had lost their ‘foreign’ accent quite quickly and now sounded like the 'host' population to all intents and purposes. Similarly, the majority of people I spoke to who had been there for a year or more, often found themselves increasingly using the 'local' phrases or colloquial language that they once found so puzzling and/or amusing. This doesn't, of course, mean that they were no longer marked out by their accents and we need to acknowledge that even where such a marker can seem benign at one moment in time, it has the potential to be transformed into something far more troubling should circumstances or relationships alter. While I found no evidence for this in my study, Favell noted the extent to which German migrants living in the UK continued to be the focus of both gentle teasing and not so gentle opprobrium in relation to particular events or periods (Favell, 2008: 140). 
In thinking about the significance of these various features, we can also return to the earlier discussion of banal, everyday and hot forms of nationalism. In the majority of instances, what we are seeing is examples of everyday nationalism as people actively reflect on slightly puzzling or sometimes amusing 'breaches' and discuss these with friends, co-workers or family. While such breaches are reported as enjoyable instances of social interaction they also reiterate the dominance of distinctly Australian norms, which (British) migrants are largely expected to conform to. We can see the power of such norms in the ways in which Steve's Australian co-workers ask him to say particular words 'all the time' - it may not be 'nasty' but it does reiterate the power of some to define what counts as amusing and what doesn't. Finally, these encounters reconfirm the existence of national categories and differences and while these are certainly not see as problematic or, indeed, insurmountable in this context, they continue to inform the ways in which people make sense of and act in the world, a key feature of the banal nationalism thesis.

In the next section, I want to shift focus to examine another form of breach, this time relating to food. This discussion is useful at it notes how particular objects and practices become labelled and understood as distinctly national in a new environment.

\section{Breaches of food and taste}

The relationship between food and nationhood has been the subject of a great deal of research over the past few years (Ichijo \& Ranta, 2016). There is also a growing literature on the significance of food to migrant communities although again much of this tends to deal with groups moving from poorer to richer countries. As Sutton observes in his review of the literature, 'food-centred nostalgia is a recurring theme in studies of diasporic or expatriate 
populations' (2010: 367). Likewise, the absence of specific foods (generally sweet or salty snacks) was lamented by a good number of the people I interviewed and the peculiarities of particular tastes could also be categorised as ‘breaches' of background expectations.

Rachel: And chocolate. Just plain chocolate because it's so different over here.

Peter: Chocolate over here has a chemical in it to stop it melting.

Rachel: That's gross, yeah (British, aged 20’s, living in Sydney)

Angela: Galaxy is my favourite.

Luke: And you come over here and it's like it’s not the same. Doesn't taste the same (British, aged 30’s, living in Queensland)

Alongside these two extracts, it's also worth noting that the majority of websites aimed at Brits living in Australia feature discussions of chocolate and, in particular, how recognisable brands such as Cadburys differ in terms of taste in the two countries. This is a fairly typical contribution;

Lizie: UK is definatley (sic) better .... IMO

I was told that something is put into Oz Cadbury's chocolate to stop it melting so quickly ... not sure whether this was a wind up though 
Vash: It's a myth. The only real difference is the type of emulsifier used in each country (http://britishexpats.com/forum/barbie-92/uk-cadbury-dairy-milk-v-australia-cadburydairy-milk-435673/)

There is a long history of work investigating the link between food and memory, notably in anthropology, and a key argument has been that 'the sensuality of food causes it to be a particularly intense and compelling medium for memory’ (Holtzman, 2006: 365). Much of this research has built on Proust's (1913) oft-cited reflections on his adult experience of eating a 'petites madeleines'. In vivid language, he describes how this particular delicacy is tied to a whole bank of long-forgotten memories from his childhood. This example, and other subsequent academic studies (See Holtzman, 2006 for an overview), point to the importance of attending to the ways in which all the senses are key to both locating people in familiar or homely spaces or, alternatively, disrupting taken-for-granted auditory, olfactory and other 'regimes'. Of particular relevance, here, is the manner in which a particular product or activity becomes categorised as distinctly national as a result of such disruption.

\section{Making sense of difference}

Perhaps the classic example of this shift comes from the work of Marcel Mauss (1973). Writing about his experiences in the First World War, Mauss noted how French soldiers struggled to use British spades, and vice versa, to dig trenches. He then argued that people growing up on different societies developed particular 'techniques of the body' which only became revealed when they interacted with 'foreigners'. In a similar vein, I want to suggest that people can also develop particular tastes that also are revealed, and then labelled, as distinctly national when they interact with 'difference'. 
For many British people growing up in Britain, eating a bar of Cadburys chocolate is likely to be a pretty unexceptional event. It's a popular product that is sold and advertised widely across the country and for most people will be a part of the backdrop to everyday life. On the production side, these snacks are often markers of banal nationalism, featuring information about where they are made, advertising and promotional offers aimed at national markets and so on. On the consumption side, their perceived status as distinctly national markers is less certain, at least during unexceptional periods ${ }^{\mathrm{i}}$.

However, unlike many ‘British’ products that are unavailable in Australia or only available for a very high price, Cadburys chocolate can be bought across the country. The breach comes from the difference in taste which is clearly and consistently defined in national terms, with the deictic phrase 'over here' used again and again. Now, in the grand scheme of things, adjusting to the taste of individual snacks isn't a major undertaking, notably given the upheaval of travelling half-way round the world! What is interesting in analytical terms is how previously unremarkable products and practices become transformed into distinctly national ones, and how a national framework continues to underpin people’s understanding of the world, as a result of these movements. These examples also encourage us to think more closely about the importance of taste, smell and, perhaps, even touch when it comes to not only memories but also how people make sense of their place in the world.

\section{Changing background expectations}

The final examples that I want to discuss not only point to the importance of everyday practices but also the extent to which people's background expectations shift over time. The latter may be of particular significance in showing how once puzzling or disorientating features of the individual's lifeworld can become accepted and, in some cases, prized. 
The first extract deals with people's engagements with a new currency and shows how this initially creates a burden as they are forced to make constant calculations in order to try and assess whether something is good value for money.

Nick: But then it [the British pound) was two and a half times [the Australian dollar]. So every time you converted it in your head it everything did seem cheaper... for a good two years I'd say we would convert everything back to English because that's what you've been brought up with so...

Linda: ...the value of something, even though you're earning Australian dollars, you could only assess its value in pounds. And then slowly but surely that goes... Well now, the last time we went back to the UK I'd say, oh that's fifty pounds how much is that in dollars? (British, aged 40’s, living in Queensland)

Subsequently, as the new system becomes familiar, indeed taken-for-granted, over a period of years, it is the return 'home' that causes a disruption to a new set of background expectations as the couple are forced to try and make fresh calculations in order to reassess the value of what once was the norm.

Another interesting example of this process can be seen in the following extract, which deals with people's everyday interactions on the street and the 'acceptable' management of personal space.

Mark: So when they are being over nice and over friendly where does it end? Because you can't be nice all the time, but that is because the UK way is that we are a bit more ... 
Layla: We don’t talk to anyone. And when you walk into shops here they talk to you, and at the beginning I absolutely hated it. I was like just leave me alone, just don’t invade my personal space .... whereas here people talk to each other, they approach each other and my initial reaction was always like ... but now when I went back to the UK and you want a bit of assistance you are like 'hello'. And I really think I much prefer that now. It has taken three years for me to get to that though. Before you just walked in there thinking oh god they are going to talk to me.

George: I thought they were mugging me when I first moved here and they started talking to me at the bus stop (British, aged 20’s, living in Sydney)

This is a fascinating exchange which points to an initial clash between what is expected and acceptable behaviour in public places and the disjuncture that all the group feel when dealing with (what they perceive to be) overly familiar strangers. In George’s case, this leads to a very real fear for his physical safety as he misreads an attempt to be polite or friendly with a threat to his person. Likewise, Layla initially dreaded going into shops as she felt that workers would continually 'breach' what she considered to be acceptable norms of behaviour, that is the would make an effort to talk to her rather than letting her browse the products independently. Over time, though, what had, at first, seemed forward and/or threatening, itself became normalised and, in Layla's case, valued. Indeed, it was something that caused her to reflect on and critically assess previously taken-for-granted forms of practice in the UK. In other words, these shifts over time point to the ways in which newer forms of behaviour come to be seen as 'normal' and part of a new set of background expectations. Finally, we have the fact that this exchange ('the UK way', 'we don’t talk to anyone’, 'here people talk to 
each other', 'I went back to the UK') and the broader discussion was framed in relation to national differences.

\section{Conclusion}

This paper has had two main objectives. First, to build on the arguments of those who pointed to the importance of theorising the different forms of nationalism - hot, banal, everyday - as part of a more dynamic analytical framework. This not only enables us to pinpoint the ways in which the same markers or practices may have very different meanings for particular groups (a joke about national differences may generate laughter in some and hostility in others) but also how these meanings shift over time as mindless markers are opened up to scrutiny or mindful ones become largely un-noticed. Finally, it has also been argued that the significance of these different forms needs to be understood in relational terms. A conflict over a material or symbolic resource may be defined as hot or everyday depending on the level of anger or, perhaps, violence it generates but these arguments often need to be justified in relation to the nation, so that they rarely challenge the primacy of nationalist principles per se. Therefore, moving beyond individual features to focus on wider, embedded social structures is absolutely crucial if we wish to understand the continuing salience of national frameworks in people’s everyday lives

The second objective was to show how the experience of middling migrants may be useful in pointing to the ways in which national frameworks continue to pattern people's everyday lives as well as the significance of often taken-for-granted features (language, food, social practices) in making places feel familiar, comfortable and secure. Likewise, by talking to people living abroad but in relatively familiar environments we can not only ask them to pinpoint a range of different breaches but also reflect on how they have dealt with or, in some cases, embraced those objects and forms of language and practice that once generated 
consternation, puzzlement or even fear.

\section{Bibliography}

Baker, C. 1997. 'Membership categorisation and interview accounts’, In D. Silverman (ed.), Qualitative Research: Theory, Method and Practice. London: Sage.

Bell, A. (2009). Dilemmas of Settler Belonging: Roots, Routes and Redemption in New Zealand National Identity Claims, The Sociological Review, 57(1), 145-162.

Berger, P., \& Luckmann, T. (1967). The social construction of reality. London: Allen Lane.

Billig, M. (1995) Banal Nationalism, London: Sage

Calhoun, C (2017) The Rhetoric of Nationalism in Skey, M \& Antonsich, M (eds) Everyday Nationhood: Theorising Belonging, Culture \& Identity After Banal Nationalism, Palgrave, MacMillan

Carter, T. J., Ferguson, M. J. \& Hassin, R. R (2011). 'Implicit nationalism as system justification: the case of the United States of America', Social Cognition, 29: 341-359.

Condor, Susan, (2000), Pride \& prejudice? Identity management in English people’s talk about 'this country', Discourse \& Society, 11:2, 75-205 
Conradson, D and Latham, A. (2005) Friendship networks and transnationality in a world city: Antipodean transmigrants in London. Journal of Ethnic and Migration Studies, 31(2), 287-305

Devos, T. \& Banaji, M. R. (2000) 'American=white?', Journal of Personality and Social Psychology 88: 447-466.

Favell, A. (2008). Eurostars and Eurocities: Free movement and mobility in an integrating Europe, Oxford: Blackwell

Fox, J., \& Miller-Idriss, C. (2008). Everyday nationhood. Ethnicities, 8(4), 536-563.

Fox, J. (2017). The edges of the nation: a research agenda for uncovering the taken-for-granted foundations of everyday nationhood. Nations and Nationalism, 23(1), 2647.

Fraser, L. and McCarthy, A. (eds.) (2012). Far from 'Home': The English in New Zealand. Dunedin:Otago University Press.

Garfinkel, H (2004) Studies in Ethnomethodology, Cambridge: Polity.

Giddens, A. (2002) Runaway world: How globalisation Is reshaping our lives. London: Profile. 
Hassin, R. R. et al. (2009). 'Précis of implicit nationalism', Annals of the New York Academy of Sciences, 1167: 135-145.

Hester, S., \& Housley, W. (Eds.). (2002). Language, Interaction and National Identity: Studies in the social organisation of national identity in talk-in-interaction. Ashgate Holtzman, J (2006) Food and Memory, Annual Review of Anthropology, 35:361-78 Ichijo, A., \& Ranta, R. (2016). Food, National Identity and Nationalism: From Everyday to Global Politics. Basingstoke: Palgrave Jones, R., \& Merriman, P. (2009). Hot, banal and everyday nationalism: Bilingual road signs in Wales. Political Geography, 28(3), 164-173.

Knott, Eleanor (2015) Everyday nationalism: a review of the literature Studies on National Movements, 3. ISSN 2295-1466

Kyriakidou, M., Skey, M., Uldam, J., \& McCurdy, P. (2017). Media events and cosmopolitan fandom:'Playful nationalism'in the Eurovision Song Contest. International Journal of Cultural Studies, 1367877917720238.

Lippi-Green, R., 1997. English with an accent: Language, ideology, and discrimination in the United States. Psychology Press.

Mauss, M. (1973). Techniques of the body. Economy and society, 2(1), 70-88. 
Medhurst, A. (2005). A national joke: Popular comedy and English cultural identities. London: Routledge.

McGlynn, C. et al. (eds.) (2011). Britishness, Identity and Citizenship the View from Abroad. Bern:Peter Lang.

Pearson, D. (2001). The politics of ethnicity in settler societies: States of unease. Basingstoke; Palgrave

Pearson, D. (2014). Ambiguous immigrants? Examining the changing status of the English in New Zealand. Nations and Nationalism, 20(3), 503-522.

Proust, M (1992/1913) In Search of Lost Time (trans: Enright, D) Chatto \& Windus, New York

Schutz, A. \& Brodersen, A. (1976). The Stranger//Collected papers. Studies in Social Theory. The Hague: Martinus Nijhoff.

Skey, M. (2010). 'A sense of where you belong in the world': national belonging, ontological security and the status of the ethnic majority in England. Nations and Nationalism, 16(4), 715-733.

Skey, M. (2011). National Belonging and Everyday Life, Palgrave Macmillan, London. 
Smith, M-P. (2001) Transnational Urbanism: Locating Globalization. Oxford: Blackwel

Smith, M-P. (2005). Transnational urbanism revisited. Journal of Ethnic and Migration Studies, 31(2), 235-244.

Sutton, D. E. (2010). Food and the Senses. Annual Review of Anthropology, 39, 209-223.

Thompson, A. (2001). Nations, national identities and human agency: putting people back into nations. The Sociological Review, 49(1), 18-32.

Van der Toorn, J., Nail, P.R., Liviatan, I. and Jost, J.T., (2014) My country, right or wrong: Does activating system justification motivation eliminate the liberal-conservative gap in patriotism?. Journal of Experimental Social Psychology, 54, pp.50-60.

United Nations, (2015). 244 million international migrants living abroad worldwide, new UN statistic reveal, http://www.un.org/sustainabledevelopment/blog/2016/01/244-millioninternational-migrants-living-abroad-worldwide-new-un-statistics-reveal/ (accessed, 24/12/17)

Wise, A. (2010). Sensuous multiculturalism: emotional landscapes of inter-ethnic living in Australian suburbia. Journal of ethnic and migration studies, 36(6), 917-937.

Wise, A. (2016). Convivial Labour and the ‘Joking Relationship’: Humour and Everyday Multiculturalism at Work. Journal of Intercultural Studies, 37(5), 481-500. 
' The 2010 take-over of Cadbury’s by the US food giant, Kraft, has very much shifted the ways in which the brand is now articulated as distinctly British and largely threatened by foreign interference. Indeed, the outcry over Kraft's hostile bid for 'one of Britain's best-loved brands' led the UK government to reformulate foreign direct investment rules in order to better protect local companies.

http://www.independent.co.uk/voices/cadburys-chocolate-fairtrade-fair-trade-mark-farmers-kraft-americanbrand-abandoned-promise-a7445826.html / http://www.bbc.co.uk/news/business-27258143 